\title{
etymologia
}

\section{The Color Puce (Pyüs)}

\section{Clyde Partin}

$F^{o}$ or those with synesthesia, in whom stimulating 1 sensory pathway gives rise to a subjective sensation of a different character, the word plague may chromatically resonate with puce. In pre-revolutionary France, an era of "evocative color nomenclature," Marie Antoinette's reign was precipitating intense criticism. Her countrymen were experiencing severe socioeconomic stress, thus her sartorial self-indulgence was much resented.

After discovering the Queen wearing a new gown, her husband, Louis XVI, the King of France, chided her, describing the dress's unflattering purple-brown hue as "couleur de puce" (color of fleas). This admonishment had the unintended consequence of promoting puce as the exclusive color worn by the French court. Puce, the French word for flea, descends from pulex (Latin). Flea droppings leave puce colored "bloodstains" on bedsheets. The role of fleas, however, as a vector for bubonic plague was not proven until about 1895 .
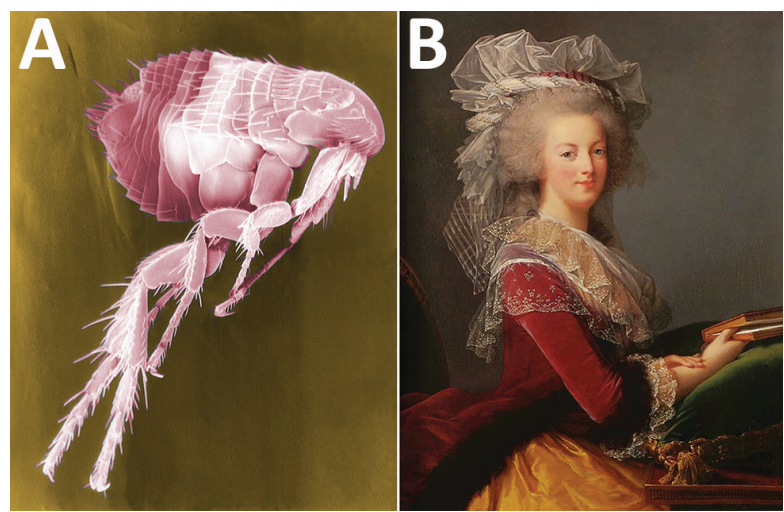

Figure. A) Digitally colored scanning electron microscopic image of a flea. Puce is a particularly difficult color to describe. Numerous shades of puce exist, some of which are associated with different anatomic areas of the flea. Image no. 11436: Janice Haney Carr/CDC. B) Portrait of Marie Antoinette painted in 1785 for the Ministry of Foreign Affairs, by Louise Élisabeth Vigée Le Brun. Private collection, Public domain, https://www.theawl.com/2017/10/ the-sexy-gross-story-of-puce. She seemed to have "preferred a shade leaning more toward ash-gray," but is seen here modeling a more standard hue of puce.

\section{Sources}

1. Stedman's Medical Dictionary. 23rd ed. Baltimore: The Williams \& Wilkins Company; 1976. p. 1392.

2. St. Clair K. The secret lives of color. New York: Penguin Books; 2017. p. 122-3.

3. Zietz BP, Dunkelberg H. The history of the plague and the research on the causative agent Yersinia

pestis. Int J Hyg Environ Health. 2004;207:165-78. https://doi.org/10.1078/1438-4639-00259

4. Plague bacteria found in Arizona fleas, by Rachael Rettner, August 14, 2017 [cited 2021 Nov 4]. https:/ / www.livescience.com/60130-plague-fleasarizona.html.)

Author affiliation: Emory University, Atlanta, Georgia, USA

Address for correspondence: Clyde Partin, Department of Internal Medicine, Emory University, 1365 Clifton Rd NE, Atlanta, GA 30322-1007, USA; email: wpart01@emory.edu

DOI: https://doi.org/10.3201/eid2802.212274 